\title{
FLUID INCLUSION INVESTIGATION OF THE NEOPROTEROZOIC LEAD-ZINC SULFIDE DEPOSIT OF NOVA REDENÇÃO, BAHIA, BRAZIL
}

\author{
ADRIANA SANCHES ROCHA GOMES ${ }^{1}$, CARLOS EDUARDO SILVA COELHO ${ }^{1,2}$ AND AROLDO MISI ${ }^{1}$
}

\begin{abstract}
The Pb-Zn (Ag) mineralizations of Nova Redenção, Una-Utinga Basin, are hosted by dolarenites, dolomicrites and siliceousferruginous breccias of the Salitre Formation, Una Group. An ore reserve of about $2.5 \mathrm{Mt}$, with average grade of $6,1 \% \mathrm{~Pb}, 0,5 \% \mathrm{Zn}, 32 \mathrm{ppm}$ $\mathrm{Ag}$ and $10 \mathrm{ppm}$ of $\mathrm{Cd}$ has been estimated by Companhia de Pesquisa de Recursos Minerais (CPRM) in the main sector of the deposit. The mineralization is composed mainly of galena and sphalerite, which occur in different ways (disseminated, stratabound, oolith and brecciacement, filling stilolytes/pockets, and veins). The orebodies are directly associated with $\mathrm{N} 50^{\circ} \mathrm{W}$ trending regional fractures and faults, which are thought to represent deep basement structures reactivated during and after the Neoproterozoic carbonate basin sedimentation. Relationships between sulfides and the shallow sedimentation facies are striking. Several evidences of early-formed sulfates have been observed, including length-slow or lutecite-type microcrystalline quartz, aggregates of quartz with gypsum structure, microcrystalline pseudo-fibrous silica nodules, indicating both a lithostratigraphic and a sedimentary facies control. The study of primary fluid inclusions in sphalerites contemporaneous to galena showed the presence of moderate to high (around $24.3 \mathrm{wt} \%$ eq. $\mathrm{NaCl}$ ) aqueous solutions, containing $\mathrm{Ca}, \mathrm{K}$ and $\mathrm{Mg}$ salts. The homogenization temperatures $(\mathrm{TH})$ have a mean value of $185^{\circ} \mathrm{C}$. Previous sulfur isotopic studies $\left(\mathrm{d}^{34} \mathrm{~S}\right)(\mathrm{Misi}$ et al.1999) in cogenetic galenasphalerite pairs also indicated temperatures in the range $140^{\circ}-180^{\circ} \mathrm{C}$. Sulfur isotopic data in sulfides and sulfates suggested that sulfur was derived from seawater, possibly by thermochemical reduction (Misi et al. 1999). The characteristics of the mineralization along with the obtained fluid inclusion and isotopic data permit to suggest the following metallogenic model for the Nova Redenção deposit: high concentration of metal brines have migrated throughout deep reactivated structures of the basement, forming sulfides by thermochemical reduction of sulfur present in the basin. The stratigraphic and sedimentary facies control is indicated by the presence of sulfates formed probably by sea-water evaporation in shallow zones of sedimentation.
\end{abstract}

Keywords: fluid inclusions, mineralization, sphalerite, salinity, composition, temperature

INTRODUCTION The $\mathrm{Pb}-\mathrm{Zn}(\mathrm{Ag})$ mineralization of the Nova Redenção located in the central-east portion of the State of Bahia, is hosted by dolarenites, dolomicrites and silica-ferruginous breccias of the Salitre Formation (Una Group), in the Una-Utinga Basin (Fig. 1) The ore reserve in the main section of the deposit (Fig. 2) has been estimated at approximately $2,5 \mathrm{Mt}$, with average grades of $6,1 \% \mathrm{~Pb}$, $0,50 \% \mathrm{Zn}, 32 \mathrm{ppm}$ of $\mathrm{Ag}$ and $10 \mathrm{ppm}$ of Cd by CPRM. The sulfide ore, composed predominantly by galena and sphalerite, occurs in different ways: disseminated, stratabound, cementing ooids and breccias, filling stilolytes, veins and pockets. It is directly associated with regional fractures and faults oriented $\mathrm{N} 50^{\circ} \mathrm{W}$ (Fig. 2). The structures were probably reactivated during and after the Neoproterozoic sedimentation of the carbonatic basin

The sulfides are associated with the facies of shallow sedimentation (evaporitic environment), suggested through the presence of microcrystalline quartz (length-slow), quartz pseudomorph of gypsum and pseudo-fibrous microcrystalline nodules of silica (Gomes 1998).

FLUID INCLUSIONS STUDIES The inclusions of primary and secondary nature in sphalerite crystals show small dimensions (5 to 10

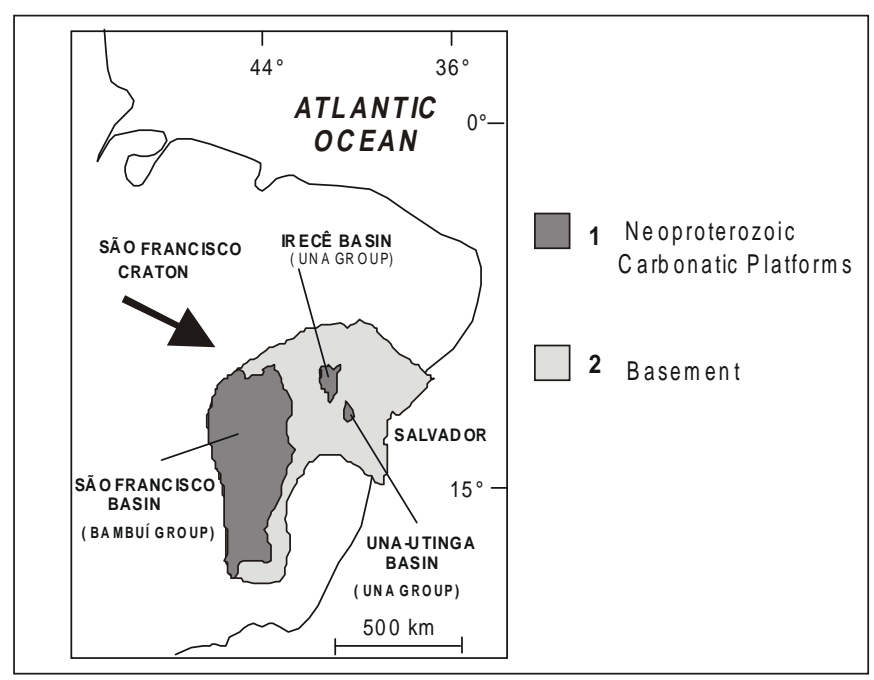

Figure 1-Simplified geological map of the São Francisco craton and location of the Una-Utinga, Irecê and São Francisco basins. Modified from Misi and Kyle (1994). $\mu \mathrm{m})$ and a variety of shapes, from octahedral negative to more rarely acicular. The inclusions within the sphalerite grains are randomly distributed (disseminated) or form trails of intragranular inclusions, generally parallel to the cleavage planes of the host crystal. Inclusions related to microfractures that cut more than one sphalerite grain are rare. The disseminated and intragranular inclusions are primary in relation to the formation of the sphalerite, therefore they can be considered as actual samples of the mineralizing fluid.

According to the fluid content at room temperature (Roedder 1984), the primary inclusions are divided into two-phase $(\mathrm{L}+\mathrm{V})$ with a degree of filling varying from 0.8 to 0.9 , and monophase ( $\mathrm{L}$ or V) inclusions. During the freezing run the microthermometric behavior of the inclusions showed the development of a 'vapor bubble' and a freezing temperature around $-60^{\circ} \mathrm{C}$, indicating they were liquid aqueous inclusions. Rare monophase inclusions never showed any phase change up to $-180^{\circ} \mathrm{C}$ and may represent leaked inclusions.

Microthermometric Data Microthermometric measurements were performed on a Chaixmeca heating-freezing stage attached to a Nikon microscope equipped with a x100 Nikon objective of the Metallogenesis Laboratory at Federal University of Bahia.

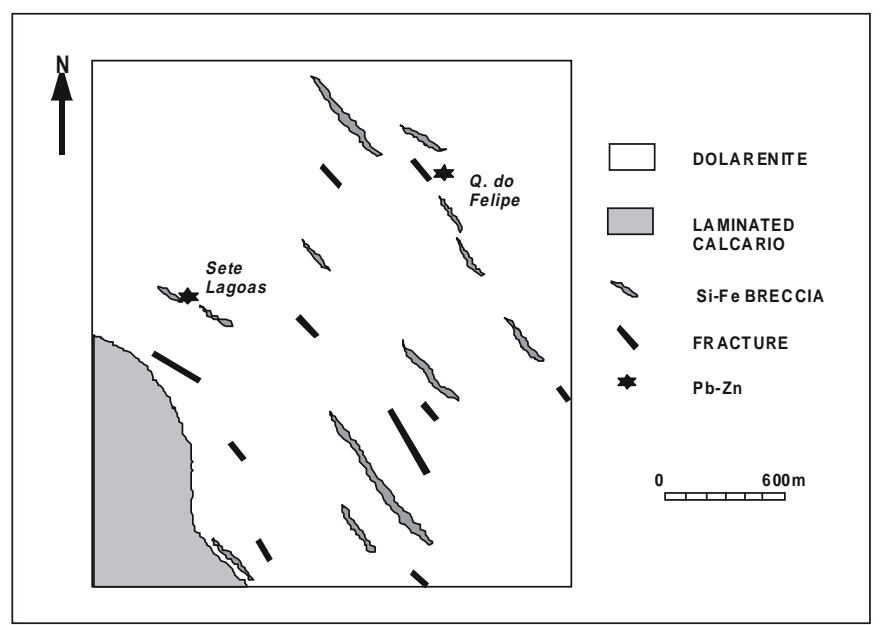

Figure 2-Simplified geological map of the mineralized area in the Neoproterozoic Una-Utinga basin, Nova Redenção. After Moraes Filho and Leal (1990).

1 Research Group on Metallogenesis, Centro de Pesquisa em Geofísica e Geologia and Curso de Pós-Graduação em Geologia, Instituto de Geociências, Universidade Federal da Bahia. Rua Caetano Moura, 123 40210-340 - Federação, Salvador-Bahia, Brazil E-mail: asrg@ufba.br, ccoelho@cpgg.ufba.br, misi@ufba.br

2 Conselho Nacional de Desenvolvimento Científico e Tecnológico 
PHASE TRANSITION IN THE COOLING RUNS During cooling runs, the monophase inclusions presented two phase changes, while the two-phase inclusions have shown a single-phase transition. In monophase inclusions the first observed phenomenon was the nucleation of a vapor bubble below $0^{\circ} \mathrm{C}$, and the development of a solid phase around $-60^{\circ} /-70^{\circ} \mathrm{C}$. This last phase transition was also observed in the two-phase inclusions. The monophase inclusions remained with the vapor bubble at room temperature after the cooling runs. This indicates these monophase inclusions are actually two-phase inclusions that were initially in the metastable state.

During heating from very low temperatures of the monophase metastable and two-phase inclusions, several phases transitions were observed between $-60^{\circ} \mathrm{C}$ and $-5^{\circ} \mathrm{C}$. About $53 \%$ of the inclusions showed only a single phase change mainly above $-28^{\circ} \mathrm{C}$ (Fig. 3).

In the inclusions that showed two phase changes four major concentrations of temperatures could be distinguished: a cluster around $-18^{\circ} \mathrm{C}$, another around $-26^{\circ} \mathrm{C}$, a third around $-42^{\circ} \mathrm{C}$, and a fourth group with figures between $-50^{\circ} \mathrm{C}$ and $-60^{\circ} \mathrm{C}$, indicating possibly the presence of $\mathrm{Ca}$ and $\mathrm{Mg}$ salts or metastable temperatures.

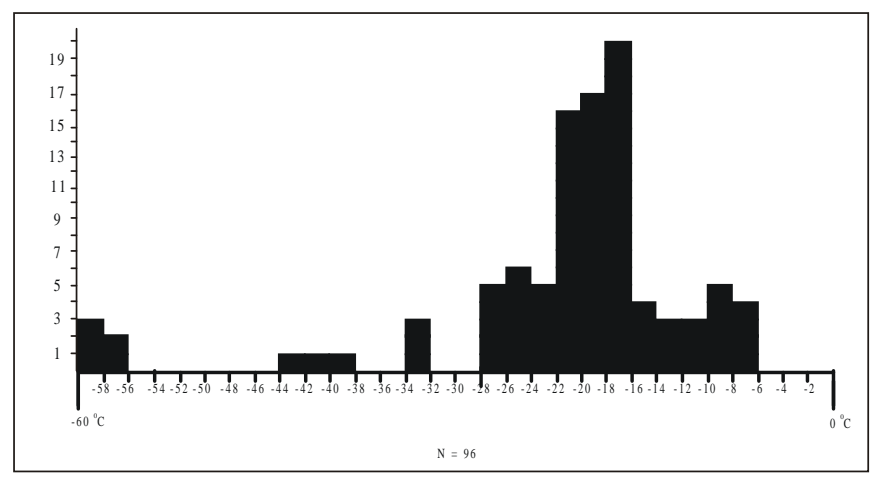

Figure 3-Histogram of the melting temperatures of the solids in inclusions that showed a single-phase transition during the re-heating.

Measurements of eutectic temperatures (Te's) have been very hard because the melting temperatures of the formed phases were generally well below the expected Te's (metastable melting). Bodnar (1998) and Burrus (1997; 1998) observed that some low eutectic melting temperatures more likely represent the devitrification of saline aqueous glass or solid state transition, which are being now observed because of the better quality of current apparatus. Furthermore, the small dimensions of the inclusions (less than $20 \mathrm{~mm}$ in average) have strongly difficulted the accurate observation of phase transitions.

SALINITY ESTIMATES About $72 \%$ of the changes in inclusions that showed just one phase change (Fig. 3), occurred above $-21.2^{\circ} \mathrm{C}$, the eutectic temperature of the $\mathrm{NaCl}-\mathrm{H}_{2} \mathrm{O}$ system. In relation to the inclusions that showed two phase transitions, about $54 \%$ displayed one of the melting temperatures greater than $-21.2^{\circ} \mathrm{C}$. On the other hand, inclusions that showed melting temperatures below $-21.2^{\circ} \mathrm{C}$ indicate more complex fluids. However as it was not possible to do any accurate observation of the melting temperatures stable of the antarcticite crystals, nor the distinction between the melting of the ice and the hydrohalite crystals. The salinity of these inclusions could not be calculated since the method of Oakes et al.(1990) need these two data. Thus the system NaCl- $\mathrm{H}_{2} \mathrm{O}$ was used to calculate the salinities of the inclusions that showed melting temperature above $-21.2^{\circ} \mathrm{C}$. The melting temperatures were distributed between $-21^{\circ}$ and $-4^{\circ} \mathrm{C}$ welldefined maximum $-17^{\circ} \mathrm{C}$.

The salinities have been calculated separately, according to the equations that include the melting temperatures of the two crystals (Goldstein and Reynolds 1994). In this way, the calculated salinities (considering the well-defined maxima of the melting temperature of the ice) varied from 10.3 to $23.3 \mathrm{wt} \%$ eq. $\mathrm{NaCl}$ (Fig. 4). In the case of the hydrohalite being the last melted crystal, the calculated salinities stay between 22.3 and 25.3 wt $\% \mathrm{NaCl}$ (Fig. 4).

Therefore, the difference between the well-defined maxim of the calculated salinities, considering ice or hydrohalite as the last melted crystal, is of about $3 \mathrm{wt} \% \mathrm{NaCl}$. Consequently, the impossibility to de- termine what was the last melting crystal during re-heating did not represent a significant oversight in the calculation of the salinity. In any way, these values revealed a high salinity mineralizing fluid.

PHASE TRANSITION IN THE HEATING RUNS The only phase transitions observed during the heating runs were the total homogenization temperatures $(\mathrm{TH})$, which always occurred to the liquid phase. The diagram of frequency distribution (Fig. 5) shows that these values vary from $80^{\circ} \mathrm{C}$ to $210^{\circ} \mathrm{C}$, albeit most of the data are comprised in a narrow interval of temperatures, between $140^{\circ} \mathrm{C}$ and $190^{\circ} \mathrm{C}$, with a well-defined maximum at $185^{\circ} \mathrm{C}$.

CONCLUSIONS The study of primary fluid inclusions in sphalerites of the Nova Redenção Pb-Zn sulfide deposit revealed two main characteristics of the mineralizing fluid: the presence of strongly saline (average $24.3 \mathrm{wt} \%$ eq. $\mathrm{NaCl}$ ) aqueous solutions formed mainly by $\mathrm{H}_{2} \mathrm{O}-\mathrm{NaCl}$, possibly with dissolved salts of $\mathrm{Ca}, \mathrm{K}$ and $\mathrm{Mg}$ and relatively high minimum trapping temperatures(well-defined maximum of $185^{\circ} \mathrm{C}$ ).

The study of sulfur isotopes in cogenetic galena-sphalerite pairs also indicated temperatures of the same order (Misi et al. 1999). Such temperatures suggest the possibility that sulfide formation could be related to thermochemical processes of reduction of the seawater sulfur.

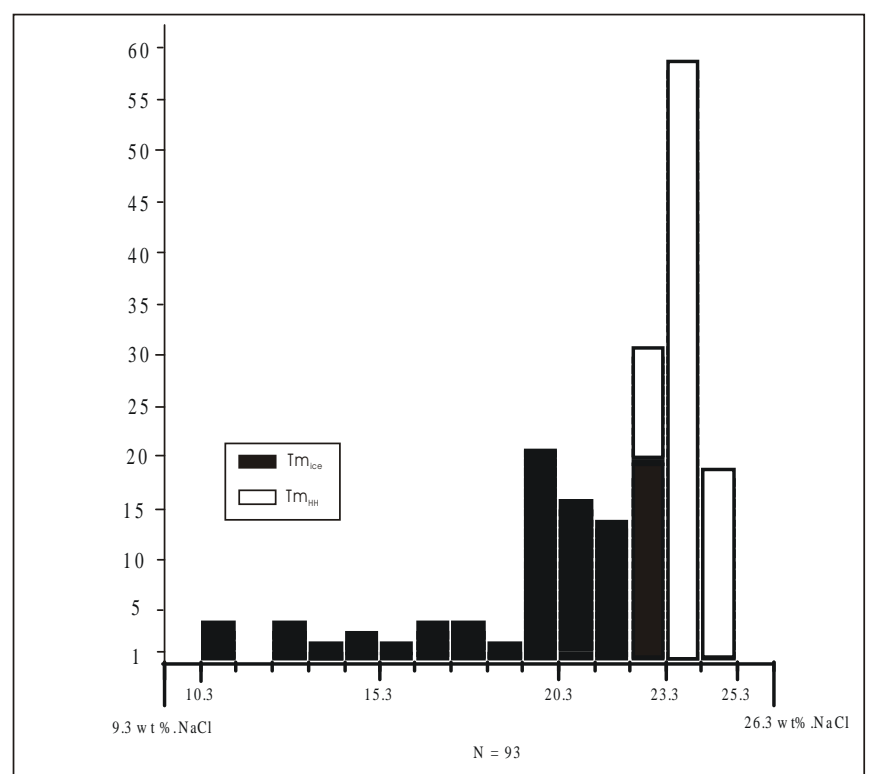

Figure 4-Histogram of the salinity calculated according to system $\mathrm{NaCl}-\mathrm{H}_{2} \mathrm{O}$, through the values of ice and hydrohalite melting.

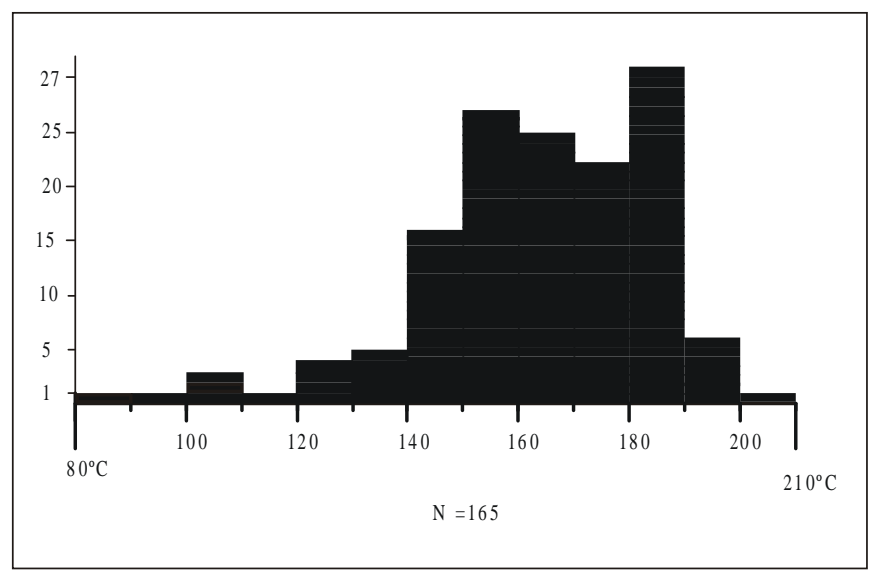

Figure 5-Histogram of total homogenization temperatures (TH) of fluid inclusions in sphalerite, Nova Redenção deposit. 
A simplified genetic model for the $\mathrm{Pb}-\mathrm{Zn}$ mineralizations of Nova Redenção could be the following: (1) heated saline solutions that would have leached metals from the basement rocks or from the sedimentary pile, would circulate through faults and fractures of the basement, reactivated during and after the basin sedimentation; (2) The formation and concentration of the sulfides would have been controlled by the presence of sulfates facies, where the sulfur was reduced mainly by thermochemical processes.
Acknowledgments The authors are grateful to the Companhia de Pesquisa de Recursos Minerais (CPRM) at Salvador, Bahia, for permitting access to the deposit area, drillholes and for fieldwork support. The authors are particularly indebted to the Conselho Nacional de Desenvolvimento Científico e Tecnológico (CNPq) for the financial support. We thank Dr. João Batista G. Teixeira for English improvement. This paper is a contribution to IGCP 450 - Base Metal Deposits of Western Gondwana.

\section{References}

Bodnar R.J. 1998. Additional discussion of apparent low temperature observations that was held in february 1998. http://www.geology.wisc.edu/ pbrown/fi/disc/ loweutec2.htm Burrus R.C. 1997. short discussion of apparent low eutectic temperature observations that was held during June 1997. http://www.geology.wisc.edu/ pbrown/fi/disc/ loweutec.html

Burrus R.C. 1998. Additional discussion of apparent low temperature observations that was held in february 1998. http://www.geology.wisc.edu/ pbrown/fi/disc/ loweutec2.htm

Goldstein R.H. \& Reynolds T.J. 1994. Systematics of Fluid Inclusions in Diagenetic Minerals. SEPM short course 31.199p.

Gomes A.S.R. 1998. Estudo das mineralizações sulfetadas de Pb-Zn (Ag) da região de Nova Redenção -BA. . Inst. de Geociências, Universidade Federal da Bahia, Bahia, M.Sc. Thesis, $92 \mathrm{p}$.

Misi A. \& Kyle R. 1994. Positive $\mathrm{d}^{13} \mathrm{C}$ excursions in the Upper Proterozoic of the Una Group, Brazil, and the genesis of phosphorite deposits: a global phenomenon? In: International Sedimentological Congress, 14, Recife, Brazil, Abstracts Volume, G55G56.
Misi A., Iyer S.S., Tassinari C.G.C., Kyle, R.J., Coelho C.E.S., Franca-Rocha W.J.S., Gomes A.S.R., Cunha I. A., Carvalho I.G. 1999. Geological and Isotopic Constraints on the Metallogenic Evolution of the proterozoic sediment-hosted $\mathrm{Pb}-\mathrm{Zn}(\mathrm{Ag})$ deposits of Brazil. Gondwana Research, 2: $47-65$

Moraes Filho O. \& Leal R.A. 1990. Lead-zinc-silver search in the municipal district of Nova Redenção (BA). In: SBG, Congresso Brasileiro de Geologia, 36, Natal, Anais, 1487 1501.

Oakes C.S., Bodnar R.J., Simonson J.M. 1990, the system $\mathrm{NaCl}-\mathrm{CaCl}_{2}-\mathrm{H}_{2} \mathrm{O}$. I. The hosts liquids at $1 \mathrm{~atm}$ total pressure. Geochimica et Cosmochimica Acta, 54: 603-610.

Roedder E. 1984. Fluid Inclusions. In: P.H. Ribbe (Ed.).Rev Mineralogy, 12. Mineralogical Society of America, $646 \mathrm{p}$.

Contribution IGC-041

Received January 28, 2000 Accepted for publication April 30, 2000 